\title{
Serological evidence of West Nile virus in wild birds in Bangladesh
}

\author{
Ariful Islam ${ }^{1}$, Shariful Islam ${ }^{1}$, Mohammad Enayet Hossain ${ }^{2}$, Jinnat Ferdous ${ }^{1}$, Josefina \\ Abedin $^{3}$, Mohammed Rahman ${ }^{2}$, Md Rahman $^{1}$, Ahsanul Haque ${ }^{4}$, and Mohammad \\ Mahmudul Hassan ${ }^{4}$ \\ ${ }^{1}$ EcoHealth Alliance \\ ${ }^{2}$ icddr,b \\ ${ }^{3}$ Institute of Epidemiology Disease Control and Research \\ ${ }^{4}$ Chittagong Veterinary and Animal Science University
}

May 11, 2020

\begin{abstract}
West Nile virus (WNV) is a vector-borne zoonotic disease maintained in a sylvatic cycle involving mosquito vectors and birds. To detect West Nile virus (WNV) and other flavivirus infections in wild resident and migratory birds, we tested 184 samples from 19 identified species within nine families collected during 2012-2016 from four districts in Bangladesh. We tested serum samples for the immunoglobulin G ( IgG) antibody to WNV using competitive Enzyme-Linked Immunosorbent Assay (c-ELISA), whereas tracheal and cloacal swabs subjected to consensus PCR for the detection of the flavivirus RNA. Overall, $11.9 \%$ ( $\mathrm{n}=22 ; 95 \%$ CI: 0.07-0.16) samples were seropositive, including $15.9 \%$ migratory wild birds and $10.7 \%$ resident wild birds. Tufted duck showed $28.5 \%$ sero-positivity, whereas crows showed $12.5 \%$ sero-positivity. None of the swab samples was positive for flavivirus RNA infection. These study findings suggest that wild birds of Bangladesh may carry WNV. We recommend continued surveillance for early detection and to better understand the epidemiology of WNV and other flavivirus circulation in both birds and mosquitoes in Bangladesh.
\end{abstract}

\section{INTRODUCTION}

West Nile virus (WNV) is an emerging zoonotic arbovirus having enveloped positive-sense single-stranded RNA belonging to the family Flaviviridae under the genus Flavivirus (Pradier, Lecollinet, \& Leblond, 2012). The WNV naturally maintain a bird-mosquito-bird cycle but sometimes can infect other mammals like human and horses as dead-end host and the mosquito genus Culex is the most potent vector of the virus (MartinezDe La Puente et al., 2018). The virus causes infrequent febrile illness, nervous disorder (encephalitis), and mortality to humans, horses, and wild birds (Michel et al., 2018). In the tropical region, Culex spp. and Aedes spp. are mainly responsible for the transmission of the virus (Khatun \& Chatterjee, 2017). Migratory birds play an essential role in the spread of WNV in Asia, Africa, and Europe (Pradier, Lecollinet, \& Leblond, 2012). During winter migration, birds carry the virus to different tropical and subtropical countries. The presence of WNV reported from different countries like Mexico, the USA, India, Pakistan, and Germany, covering various continents including Asia, Europe, Australasia, and Africa. Bangladesh lies in the subtropical region and has a moderately warm temperature (Shahid, 2010). This climate condition may increase WNV transmission by decreasing the duration for vector development and increasing the rate of mosquito biting and viral replication (Montecino-Latorre \& Barker, 2018). The virus is widespread in humans and birds of Asian countries for example $0.3 \%$ of migratory wild birds in South Korea had immunoglobulin against WNV (Yeh, Park, \& Ostlund, 2011). WNV sero-prevalence reported being 11.6\% (Khan et al., 2011) 
to $14.5 \%$ (Khatun \& Chatterjee, 2017) in humans, $1.6 \%$ in wild residents and migratory birds (Mishra et al., 2012) in our bordering country India. Moreover, WNV detected in humans and horses in Pakistan (E Khan et al., 2018; Zohaib et al., 2015). Recently, WNV has been identified in a human patient at the International center for diarrheal disease research, Bangladesh (icddr,b) (report from Prothomalo, September 25, 2019). To the best of our knowledge, no study has been conducted yet in Bangladesh to determine the status of WNV in animal's especially resident and migratory wild birds. Therefore, the present study aimed to detect the evidence of WNV in resident and migratory wild birds of Bangladesh, as the baseline information for future research.

\section{MATERIALS and METHODS}

\section{Study area and sample collection}

We sampled wild birds with the approved of the Bangladesh Forest Department, the Peoples Republic of Bangladesh (Ref. no. WASU/FAO/PSWMID-6/2012/58). We conducted a cross-sectional study to screen WNV from swabs and serum samples of 12 species of resident and migratory wild birds $(\mathrm{N}=184)$ from December 2012 to February 2016 at four different sites (Chattogram, Sunamgonj, Moulavibazar and Rajshahi district) of Bangladesh (Fig 1). The study sites were selected based on the migratory bird population. Chattogram and Rajshahi locate on the bank of River Padma and Karnaphuli, respectively, where different migratory birds visit during winter (November to February) (Islam, Das, Hossain, Lucky, \& Mostafa, 2003). In Sunamgonj and Moulavibazar, we collected samples from Tanguar and Hakaluki Haor (major wetland of Bangladesh), as a popular hub for resident as well as migratory wild birds (Elahi et al., 2014). We used mist nets and leg nooses to capture the wild birds and collected blood (0.5-3.0 mL) samples by venipuncture from jugular or wing or leg vein and placed into falcon tube $(10 \mathrm{~mL})$. We sampled the resident and migratory wild birds conveniently (as much as we caught). We separated serum within six hours of blood collection and stored at $-80^{\circ} \mathrm{c}$ freezer in the laboratory until testing. We also collected oro-pharyngeal and cloacal swab samples from captured birds and placed in cryotube containing Viral Transport Media (VTM) for detection of virus.

\section{Laboratory analysis}

We evaluated the serum samples for WNV-specific antibody with sensitivity (>85\%) and specificity (92\%) competitive Enzyme-Linked Immunosorbent Assay (c-ELISA) (ID Screen ${ }^{\circledR}$ West Nile Competition, IDVet, Montpellier, France) following the protocol described by (Curry et al., 2014). We interpreted as positive if $\mathrm{S} / \mathrm{N} \%$ [?] 40\%, negative if S/N\% $>40 \%$ and doubtful $40 \%<\mathrm{S} / \mathrm{N} \%$ [?] 50\%. We tested swab samples using Consensus Polymerase Chain Reaction (c-PCR), according to a published protocol (Moureau et al., 2007) targeting the highly conserved Flavivirus $\mathrm{NS}_{5}$ gene, which contains short amino acid motifs that are $100 \%$ identical in all known flaviviruses.

\section{Statistical evaluation}

We analyzed the collected data (both demographic and laboratory) using STATA/IC-13 (StataCorp, 4905, Lakeway Drive, College Station, Texas 77845, USA). We expressed the results as frequency (n), percentage (\%), and 95\% confidence interval (CI). We plotted the sampling locations on a map of Bangladesh using the spatial analyst tool of ArcGIS (ArcMap, version 10.2, Environmental Systems Research Institute, Redlands, California, USA).

\section{RESULT and DISCUSSION}

Overall sero-prevalence of WNV in wild birds of Bangladesh was 11.9\% ( $\mathrm{n}=22 ; 95 \%$ CI: 0.07-0.16). This result was higher than the findings of a study conducted in Spain (1.96\%) using the ELISA test (Martinez-De La Puente et al., 2018) and lower than another study of Portugal (19.8\%) (Barros et al., 2011). The hot and humid environment of Bangladesh can increase the spreading and propagation of the arthropod-borne virus (Ziegler et al., 2019). The highest sero-prevalence found in wild birds from Chattogram (25.8\%). However, no samples from Rajshahi were positive either in c-ELISA or in c-PCR. One study from India also reported a negative result of WNV in RT-PCR. However, they found antibodies in the same samples (Mishra et al., 
2012). Again, the sero-prevalence was higher in the birds captured from the wetland (14.8\%) than that of plain land (10.9\%) (Table 1). Wetlands are a suitable place where domestic birds (especially domestic ducks) as well as resident wild birds meet with migratory birds in winter. Scientists from Japan and South Korea have recently found evidence of WNV in domestic ducks that had contact with migratory birds in wetlands (Saito, Osa, \& Asakawa, 2009; Yeh et al., 2011). Additionally, a large population of mosquito in the wetland, along with low human population density, can help to maintain the virus circulation in the birds of sampled area (Martinez-De La Puente et al., 2018).

The WNV sero-prevalence in the study was higher in tufted duck (28.5\%) followed by lesser whistling duck $(22.7 \%)$, Asian pied starling $(20.9 \%)$, and crow (12.5\%). Contrarily, none of the northern pintail, whitethroated kingfisher, rock pigeon, seagull, house sparrow, common moorhen, common myna, and barn owl were positive for WNV (Table 1). We sampled all the tufted and lesser whistling ducks from Hakaluki Haor, and Moulavibazar the most significant wetland of Bangladesh. This area also serves as the primary wintering ground for birds migrating in both the Central Asian and Eastern Asian-Australian flyways (El-Shesheny et al., 2018). The domestic ducks and resident wild birds of this area contact with migratory birds considered as the first-line contact, which may facilitate the dissemination of WNV to the other birds. Previously, different bird species like hummingbird, cormorant, ring-billed gull, mourning dove (Barbachano-Guerrero et al., 2019), northern cardinal, rock dove (Komar et al., 2001), purple swamphen, little egret, black ibis, spot-billed duck, common coot, mallard, ruff, purple heron (Mishra et al., 2012) was seropositive for WNV. But house sparrow and chicken had lower seroprevalence than expected (Komar et al., 2001). Among all songbirds, common grackles have a higher amount of viremia (Torres, Steel, \& Varian-Ramos, 2018). Moreover, adult birds were found to be more positive than juveniles (Beveroth, Ward, Lampman, Ringia, \& Novak, 2006).

The virus is prevalent in birds as well as in human of our neighboring countries like India (Khan et al., 2011; Mishra et al., 2012; Shukla et al., 2012) and Pakistan (E. Khan et al., 2018; Zohaib et al., 2015). India shares borders with Bangladesh, which facilitates human and bird movement between the two countries. As a result, WNV can spread to Bangladesh by the movement of humans as well as birds from India. Moreover, climate change and its consequences on the potential vectors of WNV or bird migration routes have an impact on the distribution of the disease (Pradier et al., 2012). Migratory birds might be an important source of WNV (Dhama, Mahendran, \& Tomar, 2008) because they come from European countries to Bangladesh every year (as they transit in different countries) to survive from extreme cold, which may act as a source of transmission to our resident wild birds. Other factors that influence the viral transmission cycle are season, temperature, humidity, etc. (Mackenzie \& Williams, 2009; Martinez-De La Puente et al., 2018; Montecino-Latorre \& Barker, 2018). Our study had some limitations; we tested a small number of samples and conducted a serological survey without a serum neutralization test, which may cross-react with other flavivirus antibodies. Though we used a serological test, this study provides baseline information on the presence of WNV antibodies in wild birds in Bangladesh.

\section{Conclusion}

We identified the WNV antibody for the first time in resident wild birds and migratory wild birds of different areas of Bangladesh. However, no WNV genomic RNA was detected. It refers to the migration of birds as a possible source of transmission in our country. Future studies should be directed to continuous surveillance of the virus using a virus neutralization test (VNT) in humans and birds to prevent possible outbreaks and to identify the circulating strains in the country.

\section{Acknowledgments}

We acknowledge FAO, Bangladesh, and the Centre for Integrative Ecology at Deakin University, Australia, for their financial support. USAID's Emerging Pandemic Threats support Ariful Islam and Shariful Islam PREDICT program (Cooperative Agreement No.AID-OAA-A-14-00102) through EcoHealth Alliance. We thank the Bangladesh Forest Department and the Ministry of Environment and Forest for permission to conduct this study. We thank Bilal, Kuto (CVASU), for their contributions to this study. 
Conflict of interest: The authors have no conflict of interest.

Ethical statement: We conducted this study approved by the Animal Ethics Committee Burwood (AECB), Deakin University (ref number: AEX04-2016), Australia, and the Chattogram Veterinary and Animal Sciences University Animal Experimentation Ethics Committee (ref. no. CVASU/Dir (R and E) AEEC/2015/02), Bangladesh.

Data availability statement: The data that support the findings of this study are available on request from the corresponding author. The data are not publicly available due to privacy or ethical restrictions.

ORCID: https://orcid.org/0000-0001-6495-4637

\section{References}

Barbachano-Guerrero, A., Vasquez-Aguilar, A. A., Aguirre, A. A., Norzagaray, A. A. Z.-., Gonzalez, E. C., Terrazas, A. L., \& Faisal, J. L. A.-. (2019). West Nile Virus Prevalence in Wild Birds from Mexico.Journal of wildlife diseases, 55 (2), 425-431.

Barros, S. C., Ramos, F., Fagulha, T., Duarte, M., Henriques, M., Luis, T., \& Fevereiro, M. (2011). Serological evidence of West Nile virus circulation in Portugal. Veterinary microbiology, 152 (3-4), 407-410.

Beveroth, T. A., Ward, M. P., Lampman, R. L., Ringia, A. M., \& Novak, R. J. (2006). Changes in seroprevalence of West Nile virus across Illinois in free-ranging birds from 2001 through 2004. The American journal of tropical medicine and hygiene, 74 (1), 174-179.

Curry, P. S., Ribble, C., Sears, W. C., Hutchins, W., Orsel, K., Godson, D., . . . Kutz, S. J. (2014). Blood collected on filter paper for wildlife serology: Detecting antibodies to Neospora caninum, West Nile virus, and five bovine viruses in reindeer. Journal of wildlife diseases, 50 (2), 297-307.

Dhama, K., Mahendran, M., \& Tomar, S. (2008). Pathogens transmitted by migratory birds: threat perceptions to poultry health and production.International Journal of Poultry Science, 7 (6), 516-525.

El-Shesheny, R., Feeroz, M. M., Krauss, S., Vogel, P., McKenzie, P., Webby, R. J., \& Webster, R. G. (2018). Replication and pathogenic potential of influenza A virus subtypes H3, H7, and H15 from free-range ducks in Bangladesh in mammals. Emerging microbes 83 infections, 7 (1), 1-13.

Elahi, R., Islam, A., Hossain, M. S., Mohiuddin, K., Mikolon, A., Paul, S. K., . . . Alam, M. S. (2014). Prevalence and diversity of avian haematozoan parasites in wetlands of Bangladesh. Journal of parasitology research, 2014 .

Islam, M., Das, B., Hossain, K., Lucky, N., \& Mostafa, M. (2003). A study on the occurrence of poultry diseases in Sylhet region of Bangladesh. International Journal of Poultry Science, 2 (5), 354-356.

Khan, E., Barr, K. L., Farooqi, J. Q., Prakoso, D., Abbas, A., Khan, Z., . . . Long, M. (2018). Human West Nile Virus Disease Outbreak in Pakistan, 2015-2016. Front Public Health, 6 , 20. doi:10.3389/fpubh.2018.00020

Khan, E., Barr, K. L., Farooqi, J. Q., Prakoso, D., Abbas, A., Khan, Z. Y., . . . Long, M. T. (2018). Human West Nile Virus Disease Outbreak in Pakistan, 2015-2016. Front Public Health, 6 , 20. doi:10.3389/fpubh.2018.00020

Khan, S. A., Dutta, P., Khan, A. M., Chowdhury, P., Borah, J., Doloi, P., \& Mahanta, J. (2011). West nile virus infection, Assam, India.Emerg Infect Dis, 17 (5), 947.

Khatun, T., \& Chatterjee, S. (2017). Emergence of West Nile virus in West Bengal, India: a new report. Transactions of The Royal Society of Tropical Medicine and Hygiene, 111 (4), 178-184.

Komar, N., Panella, N. A., Burns, J. E., Dusza, S. W., Mascarenhas, T. M., \& Talbot, T. O. (2001). Serologic evidence for West Nile virus infection in birds in the New York City vicinity during an outbreak in 1999. Emerging Infectious Diseases, 7 (4), 621. 
Mackenzie, J., \& Williams, D. (2009). The zoonotic flaviviruses of Southern, South-Eastern and Eastern Asia, and australasia: the potential for emergent viruses. Zoonoses and public health, 56 (6-7), 338-356.

Martinez-De La Puente, J., Ferraguti, M., Ruiz, S., Roiz, D., Llorente, F., Perez-Ramirez, E., . . . Figuerola, J. (2018). Mosquito community influences West Nile virus seroprevalence in wild birds: implications for the risk of spillover into human populations. Scientific reports, 8 (1), 1-7.

Michel, F., Fischer, D., Eiden, M., Fast, C., Reuschel, M., Muller, K., . . . Schwehn, R. (2018). West Nile virus and Usutu virus monitoring of wild birds in Germany. International journal of environmental research and public health, 15 (1), 171.

Mishra, N., Kalaiyarasu, S., Nagarajan, S., Rao, M. V. S., George, A., Sridevi, R., . . . Newman, S. H. (2012). Serological evidence of West Nile virus infection in wild migratory and resident water birds in Eastern and Northern India. Comparative immunology, microbiology and infectious diseases, 35 (6), 591-598.

Montecino-Latorre, D., \& Barker, C. M. (2018). Overwintering of West Nile virus in a bird community with a communal crow roost.Scientific reports, 8 (1), 1-13.

Moureau, G., Temmam, S., Gonzalez, J., Charrel, R., Grard, G., \& De Lamballerie, X. (2007). A real-time RT-PCR method for the universal detection and identification of flaviviruses. Vector-Borne and Zoonotic Diseases, 7 (4), 467-478.

Pradier, S., Lecollinet, S., \& Leblond, A. (2012). West Nile virus epidemiology and factors triggering change in its distribution in Europe. Rev Sci Tech, 31 (3), 829-844.

Saito, M., Osa, Y., \& Asakawa, M. (2009). Antibodies to flaviviruses in wild ducks captured in Hokkaido, Japan: risk assessment of invasive flaviviruses. Vector-Borne and zoonotic diseases, 9 (3), 253-258.

Shahid, S. (2010). Recent trends in the climate of Bangladesh.Climate Research, 42 (3), 185-193.

Shukla, J., Saxena, D., Rathinam, S., Lalitha, P., Joseph, C. R., Sharma, S., . . . Parida, M. (2012). Molecular detection and characterization of West Nile virus associated with multifocal retinitis in patients from southern India. International Journal of Infectious Diseases, 16 (1), e53-e59.

Torres, A. R., Steel, J. J., \& Varian-Ramos, C. W. (2018). The Prevalence of West Nile Virus Antibodies in Blood Samples from Song Birds Collected from the Fountain Creek Region of Colorado. El Rio: A Student Research Journal, 1 (1).

Yeh, J.-Y., Park, J.-Y., \& Ostlund, E. N. (2011). Serologic evidence of West Nile Virus in wild ducks captured in major inland resting sites for migratory waterfowl in South Korea. Veterinary microbiology, 154 (1-2), 96-103.

Ziegler, U., Luhken, R., Keller, M., Cadar, D., Van Der Grinten, E., Michel, F., . . . Lachmann, L. (2019). West Nile virus epizootic in Germany, 2018. Antiviral research, 162 , 39-43.

Zohaib, A., Saqib, M., Beck, C., Hussain, M., Lowenski, S., Lecollinet, S., . . . Saqalein, M. (2015). High prevalence of West Nile virus in equines from the two provinces of Pakistan. Epidemiology 83 Infection, 143 (9), 1931-1935.

https://www.prothomalo.com/bangladesh/article/1616038/\%E0\%A6\%AC\%E0\%A6\%BE\%E0\%A6\%82\%E0\%A6\%B2\%E0\%A

\section{Table}

Table 1. Univariate association between West Nile Virus sero-prevalence and selected factors $(\mathrm{N}=184)$.

\section{Figure}

Fig. 1. Study sites for estimating sero-prevalence of West Nile Virus in resident and migratory wild birds $(\mathrm{N}=184)$ with their sample size and \% of positive species in four different location of Bangladesh in December 
2012 to February 2016.

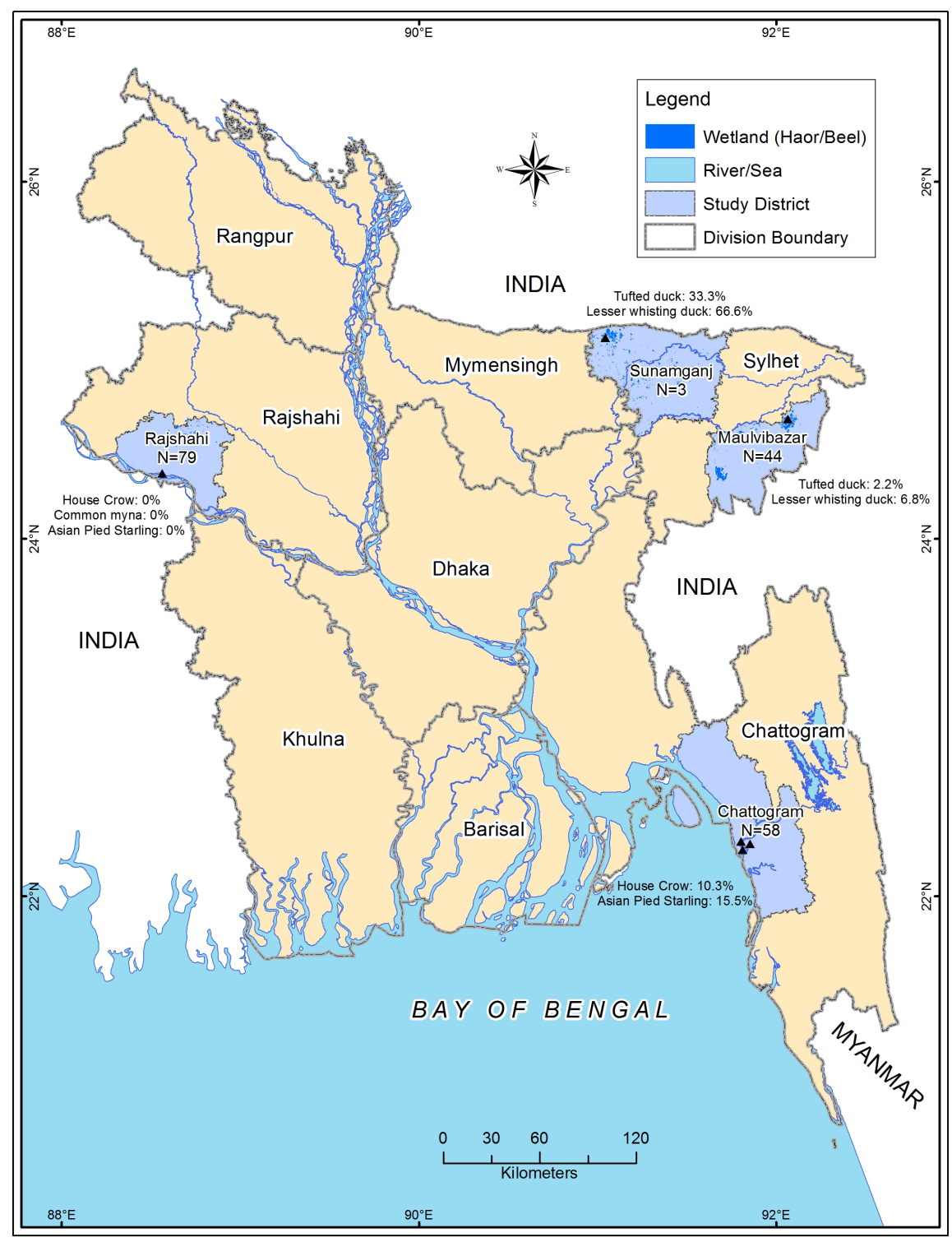

\section{Hosted file}

Table 1.docx available at https://authorea.com/users/320785/articles/450184-serologicalevidence-of-west-nile-virus-in-wild-birds-in-bangladesh 